\title{
INTEGRATED FARM ENVIRONMENTAL MANAGEMENT AND BIODIVERSITY CONSERVATION: A CASE STUDY IN THE CARATINGA BIOLOGICAL STATION (MINAS GERAIS STATE, BRAZIL) ${ }^{1}$
}

\author{
Janaína Mendonça Pereira², Jane Siqueira Lino ${ }^{3}$, \\ Cláudio César de Almeida Buschinelli ${ }^{3}$, Inácio de Barros ${ }^{4}$, Geraldo Stachetti Rodrigues ${ }^{5}$
}

\begin{abstract}
RESUMO
GESTÃO AMBIENTAL DE ESTABELECIMENTOS

RURAIS E CONSERVAÇÃO DA BIODIVERSIDADE: UM ESTUDO DE CASO NO ENTORNO DA ESTAÇÃO BIOLÓGICA DE CARATINGA (MG)
\end{abstract}

A Estação Biológica de Caratinga é uma importante reserva da Mata Atlântica, prioridade nacional para conservação do bioma, por abrigar uma das maiores populações do muriquido-norte, a maior espécie de primatas criticamente ameaçada das Américas. Estudos sobre a demografia desta população indicam condições favoráveis a um rápido crescimento, enfatizando a importância de se promover a expansão dos habitats localmente disponíveis. No presente estudo, estabelecimentos rurais vizinhos à reserva foram envolvidos em um programa participativo de recomposição de corredores de fauna, via gestão ambiental, com o sistema APOIA-NovoRural, que consiste de 62 indicadores integrados, em cinco dimensões de sustentabilidade: i) Ecologia da paisagem; ii) Qualidade ambiental; iii) Valores socioculturais; iv) Valores econômicos; e v) Gestão e administração. Os resultados relativos aos indicadores de Ecologia da paisagem (aqueles mais relacionados com a proteção da biodiversidade) demonstraram um adequado desempenho ambiental para as atividades produtivas, nos estabelecimentos estudados, enquanto, por outro lado, apontaram necessidade de melhorias na conservação dos habitats naturais. Relatórios de Gestão Ambiental produzidos nas avaliações e oferecidos aos produtores envolvidos incluíram mapeamento de recomendações para recomposição florestal e implementação de corredores de fauna, favorecendo a conexão da área principal da reserva com o segundo maior fragmento florestal existente na região.

PALAVRAS-CHAVE: Avaliação de impacto ambiental; desenvolvimento rural; corredores de fauna; APOIA-NovoRural.

\section{INTRODUCTION}

Recognition of the environmental impacts of an expanding agricultural sector worldwide has

\section{ABSTRACT}

The Caratinga Biological Station (CBS) is an important preserve of the Brazilian Atlantic Rain Forest, defined as a national priority for the conservation of this highly fragmented biome and shelter to the largest existing population of the northern muriqui, the critically threatened largest monkey species of the Americas. Extensive research on the demography of this population has indicated favorable conditions for growth, pointing out the importance of promoting expansion of the locally available habitat. In the present study, rural establishments neighboring the CBS were involved in a participatory program for wildlife corridor restoration, by means of the application of a 'System for Weighted Environmental Impact Assessment of Rural Activities' (APOIA-NovoRural), which consists of 62 indicators integrated in five sustainability dimensions: i) Landscape ecology; ii) Environmental quality; iii) Socio-cultural values; iv) Economic values; and v) Management and administration. Results regarding the Landscape ecology indicators (those most related with fauna protection) attested to the adequate performance of productive activities in the studied establishments, while pointed out the need for improvements in natural habitats conservation. The Environmental Management Reports issued to the farmers included mapped recommendations for forest restoration and wildlife corridors implementation, favoring the connection of the main preserved area of CBS with the second largest forest fragment in the region.

KEY-WORDS: Environmental Impact Assessment; rural development; wildlife corridors; APOIA-NovoRural.

led to numerous initiatives to provide management options to farmers, aiming to repair some of the environmental damage caused by agricultural intensification, ensure a more sustainable exploitation

1. Trabalho recebido em jul./2009 e aceito para publicação em nov./2010 (nº registro: PAT 6730/ DOI: 10.5216/pat.v40i4.6730).

2. Instituto Estadual de Florestas (IEF), Regional Rio Doce, Governador Valadares, MG, Brazil.

E-mail: janaina.pereira@meioambiente.mg.gov.br.

3. Empresa Brasileira de Pesquisa Agropecuária, Embrapa Meio Ambiente, Environmental Management Laboratory, Jaguariúna, SP, Brazil.E-mails: jane-lino@hotmail.com, buschi@cnpma.embrapa.br.

4. Institut National de la Recherche Agronomique (INRA), Unité de Recherche Agropédoclimatique da la Zone Caraïbe, Petit-Bourg, Guadeloupe, France.E-mail: indebarros@antilles.inra.fr.

5. Embrapa Labex Europe, Technologies for the Sustainability of Agroecosystems, Montpellier, France. E-mail: stacheti@cnpma.embrapa.br. 
of natural resources and improve the ecological status of agricultural landscapes. A consistent side effect of agricultural expansion and intensification has been the fragmentation and isolation of natural habitats within an increasingly unsuitable matrix for many species (Donald et al. 2001). Habitat fragmentation and its effects lead to a range of ecological and ecosystem changes. Among these, biodiversity attributes, such as species composition, community structure, population dynamics, behavior, breeding success, and individual fitness are negatively affected (Bayne \& Hobson 1997, Laurance et al. 2002, Fahrig 2003, Silva Júnior \& Pontes 2008).

The threats of fragmentation to biodiversity were made evident in the theories developed by MacArthur \& Wilson (1967), which related fragment size, isolation, and perturbation to patterns of species richness and population turnover on oceanic islands. It was soon realized that most of those theoretical fundaments might be applied to isolated patches of habitat on the mainland (Diamond 1975, May 1975). Theory quickly filtered through into conservation practice, and wildlife corridors and stepping-stones became recognized as potential ways of reducing fragmentation effects (Cullen Júnior et al. 2003, Brito et al. 2008, Uezu et al. 2008).

Corridors are now widely used in conservation practices at a range of spatial scales, from tens of meters to hundreds of kilometers, and landscapescale conservation is starting to replace the protection of isolated patches as a key conservation objective (Opdam \& Wascher 2004, Horskins et al. 2006). However, because large programs aiming at extending wildlife corridors among fragment patches are usually expensive and may result in reduced yields, most of these environmental management initiatives have been limited to richer countries of the northern hemisphere, where agricultural intensification has generally been greatest (Donald 2004). However, tropical environments shelter most of the biological wealth of the planet (Bruner et al. 2001), therefore, alternative non-expensive solutions to align agricultural production with sustainable development and biodiversity conservation are urgently required.

This is of special value for the dwindling, highly fragmented remaining areas of the Brazilian Atlantic Rain Forest (Ranta et al. 1998), a world hotspot of major importance not only due to its continuing rapid pace of loss to deforestation, but, moreover, due to its outstanding content of endemic and threatened species (Myers et al. 2000, Martins 2005, Martini et al. 2007). One of the most outstanding areas protected under the National Conservation Unit System as 'Private Reserve of the Natural Patrimony', the Caratinga Biological Station (CBS) is a veritable jewel of the Atlantic Rain Forest. Defined as a national priority for preservation of the biome (Preserve Muriqui 2007), the CBS shelters some 362 vertebrate species, 79 of which are mammals (Fonseca 2003), including one of the largest existing populations of the northern muriqui (Brachyteles hypoxanthus [Kuhl, 1820], Chiarello \& Melo 2001, Strier et al. 2004).

The northern muriqui is the largest monkey species of the Americas and largest mammal endemic to Brazil (Conservation International 2001), and it is critically threatened (Mittermeier et al. 2006). The visibility of this flagship species and a public consensus regarding the worth of its preservation has incited extensive research on the suitability of habitats and population viability (Strier 1991, Brito \& Grelle 2006), stressing the importance of extending wildlife corridors and connectivity among forest patches in the local muriqui population range.

More recently, environmental education campaigns and farmers' organization initiatives have been carried out at CBS, in order to further promote awareness about the uniqueness of the preserve and the importance of its northern muriqui population (Pontual et al. 2005, Strier et al. 2006). Indeed, as biodiversity conservation becomes a priority objective for local sustainable development, it necessitates the involvement of the local community and especially of local farmers (McNeely \& Schroth 2006, Norris 2008).

The involvement of local farmers in biodiversity conservation initiatives is especially needed in highly fragmented habitats that are most vulnerable to impacts originating in the surrounding landscape (Ochoa-Gaona et al. 2004), caused by agricultural mismanagement (soil erosion, pesticide drift, burning, etc.), or due to resource requirements and over-exploitation (e.g. firewood gathering and land use changes). Natural vegetation recovery can help circumvent both these sources of pressures (Clergue et al.2005), by offering some of the required resources through wise management (soil quality reclamation, wind barriers, refuge for natural enemies of pests, and firewood harvest areas) and providing 
an effective buffer for the main preserved areas (Saunders et al. 1991).

In this sense, aspects relative to the local landscape management, including land use changes, fauna distribution (Hilty et al. 2006), and restoration efforts (Crossmann et al. 2007) are to be assessed in conjunction with aspects relative to the economic feasibility of the agricultural activities (Daugherty 2005). This means that productive efficiency and socio-economic factors influencing farmers' livelihood must be considered together, in order to bring synergy between environmental restoration (the nature conservancy side of the equation) and rural development (the socio-economic viability side of the equation). Hence, promotion of forest recovery, extension of wildlife corridors, and increased connectivity of natural habitats in the landscape warrant integrated environmental management approaches, calling upon the farmers to lead the decision making and implementation processes (Donald \& Evans 2006, Vanclay 2007).

A proposed approach to organize the information on pressures imposed by agriculture onto the landscape and define appropriate corrective management options is the application of sustainability indicators (Bosshard 2000). Ideally, these indicators are integrated in 'Impact Assessment Systems' that may span increasing levels of complexity and goal requirements for environmental management (Monteiro \& Rodrigues 2006). A method of choice, specifically designed to the context of agriculture and rural development, is the 'System for Weighted Environmental Impact Assessment of Rural Activities' (APOIA-NovoRural, Rodrigues \& Campanhola 2003).

This method has been successfully applied towards the environmental management of rural territories (Rodrigues et al. 2006), large scale rural development programs (Rodrigues \& Moreira-Viñas 2007), agricultural productive sectors (Rodrigues et al. 2008a) and production chains (Rodrigues et al. 2007, 2009a), and around biodiversity protection areas (Rodrigues et al. 2008b). The approach has been indicated for planning rural landscape restoration initiatives, based on the assessment of the local environmental context and favoring farmers' involvement in decision-making, according to their implementation capacity.

In the present study, this integrated and participatory approach has been exercised to promote awareness about the uniqueness of the CBS and the importance of its biodiversity among local landowners. The assumption is that it is only through improved agricultural performance that farmers may become able to dedicate resources and efforts towards conservation of high value natural habitats, including restoration of wildlife corridors.

Based on this assumption, the objectives of the work presented in this paper have been to extend environmental assessment procedures onto selected rural establishments neighboring the preserved areas of the CBS, to organize demonstration units for environmental management, and to map the feasibility of restoring forest patches and conforming wildlife corridors to improve the range and conservation of the local northern muriqui population.

\section{MATERIAL AND METHODS}

Study site: Caratinga region and the CBS

The region of Caratinga (Minas Gerais State, Brazil - Figure 1) was an important coffee-producing

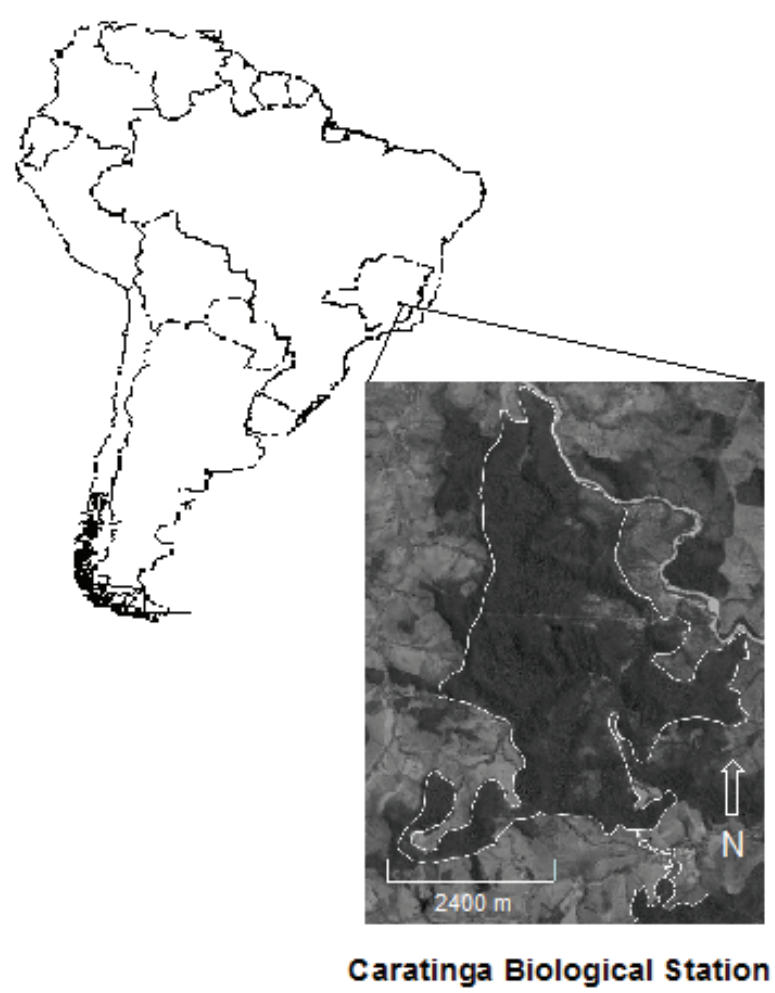

Figure 1. Location of the Caratinga Biological Station, in Minas Gerais State, Brazil, showing the forest preservation area in the matrix of pastures characteristic of the region (Digital Globe image, September $30^{\text {th }}, 2005$ ). 
area, until the destabilization of the international market, during the World War II, when the area faced a $760 \%$ expansion of pastures, accounting for the current predominance of small dairy farms, which were mostly developed with low technological standards in steep, erosion-prone, low-chemicalfertility soils (Bandeira 1970). The region is dominated by semi-deciduous Atlantic rainforests, with an average of 1,000 $\mathrm{mm}$ rainfall annually and a distinct dry season lasting 5 to 6 months (from May through October).

The Caratinga Biological Station (CBS) is a conservation unit of approximately 1,000 ha run by Conservation International, with altitudes ranging from $318 \mathrm{~m}$ to $628 \mathrm{~m}$, at general coordinates $19^{\circ} 43^{\prime} 30^{\prime \prime} \mathrm{S}$ and $41^{\circ} 49^{\prime} 22^{\prime \prime} \mathrm{W}$. The station is housed within the 'Private Reserve of the Natural Patrimony Feliciano Miguel Abdala', established in 2001 as a permanent preserve registered with the National Institute for the Environment (Ibama). The best known feature of CBS is its northern muriqui population (Fonseca 2003).

\section{Rural establishments as environmental management demonstration units}

Four of 47 rural establishments neighboring the CBS were selected after contacts with farmers who were frequently involved in environmental education projects developed by Conservation International and other environmental and community development agencies (Pontual \& Boubli 2005, Pontual et al. 2005, Strier et al. 2006). These farmers agreed to serve as demonstration units for the present study and to have their results published and presented to other members of the community. These selected establishments were representative of the range of typical tenancies in the region, including two smaller family farms, one dedicated to organic horticulture and the other to milk production; a medium sized, diversified dairy family farm; and one larger, marketoriented, specialized dairy farm (Table 1).

All selected establishments maintain patches of forest and other natural habitats that are either directly connected to the CBS and potentially utilized by the muriquis, or else are close enough for connections to be rapidly reestablished through vegetation recovery efforts. These natural habitat areas were quantified and classified in terms of conservation status by a combination of landscape ecology indicators, considering their potential for establishing wildlife corridors and natural buffer areas for protection of the main preserved lands. A summary of the characteristics of these natural habitats in the rural establishments studied are shown in Table 2.

\section{Impact assessment and environmental management system}

Integrated environmental assessments in these rural establishments were carried out with the APOIA-NovoRural system (Rodrigues \& Campanhola 2003, Rodrigues et al. 2010). This method consists of a set of 62 integrated indicators, formulated towards the systemic assessment of environmental performance considering five sustainability dimensions: i) Landscape ecology; ii) Environmental quality (atmosphere, water, and soil); iii) Socio-cultural values; iv) Economic values; and v) Management and administration.

The APOIA-NovoRural comprises a set of scaling checklists formulated to automatically transform all indicators' impact indexes into utility values (scale normalized from 0 to 1 , with the conformity baseline modeled as 0.7; Bisset 1987). Indicators are quantitatively assessed based on a field survey in the rural establishment, carried out with

Table 1. Location and productive characteristics of the four rural establishments selected as environmental management demonstration units around the Caratinga Biological Station (Minas Gerais State, Brazil).

\begin{tabular}{|c|c|c|c|c|}
\hline \multirow{2}{*}{ Characteristics } & \multicolumn{4}{|c|}{ Establishments } \\
\hline & $\mathrm{A}$ & B & $\mathrm{C}$ & $\mathrm{D}$ \\
\hline Latitude & $19^{\circ} 41^{\prime} 02^{\prime \prime} \mathrm{S}$ & $19^{\circ} 44^{\prime} 17^{\prime \prime} \mathrm{S}$ & $19^{\circ} 42^{\prime} 28^{\prime \prime} \mathrm{S}$ & $19^{\circ} 45^{\prime} 05^{\prime \prime} \mathrm{S}$ \\
\hline Longitude & $41^{\circ} 50^{\prime} 35^{\prime \prime} \mathrm{W}$ & $41^{\circ} 50^{\prime} 20^{\prime \prime} \mathrm{W}$ & $41^{\circ} 50^{\prime} 10^{\prime \prime} \mathrm{W}$ & $41^{\circ} 48^{\prime} 30^{\prime \prime} \mathrm{W}$ \\
\hline Altitude & $345 \mathrm{~m}$ & $436 \mathrm{~m}$ & $435 \mathrm{~m}$ & $404 \mathrm{~m}$ \\
\hline Total area (ha) & 9.0 & 10.0 & 22.0 & 85.0 \\
\hline Main productive activity & Organic horticulture & $\begin{array}{c}\text { Dairy and coffee } \\
\text { production }\end{array}$ & $\begin{array}{l}\text { Dairy and diversified } \\
\text { crops and livestock }\end{array}$ & $\begin{array}{l}\text { Specialized, market- } \\
\text { oriented dairy farm }\end{array}$ \\
\hline
\end{tabular}


Table 2. Characteristics of natural habitats occurrence (hectares and percent coverage) in the rural establishments selected as environmental management demonstration units around the Caratinga Biological Station (Minas Gerais State, Brazil).

\begin{tabular}{|c|c|c|c|c|c|c|c|c|}
\hline \multirow{3}{*}{ Habitat types } & \multicolumn{8}{|c|}{ Establishments total area (ha) } \\
\hline & \multicolumn{2}{|c|}{$\begin{array}{l}\text { A } \\
(9)\end{array}$} & \multicolumn{2}{|c|}{$\begin{array}{c}\mathrm{B} \\
(10)\end{array}$} & \multicolumn{2}{|c|}{$\begin{array}{l}\mathrm{C} \\
(22)\end{array}$} & \multicolumn{2}{|c|}{$\begin{array}{c}\mathrm{D} \\
(85)\end{array}$} \\
\hline & ha & $\%$ & ha & $\%$ & ha & $\%$ & ha & $\%$ \\
\hline Semi-deciduous forests & 3.76 & 94 & 1.6 & 80 & 3.52 & 88 & 14.55 & 97 \\
\hline Wetlands & 0.20 & 5 & & & & & 0.15 & 1 \\
\hline Pond/ dams & & & 0.1 & 5 & 0.40 & 10 & 0.15 & 1 \\
\hline Rivers/ streams & 0.04 & 1 & 0.3 & 15 & 0.08 & 2 & 0.15 & 1 \\
\hline $\begin{array}{l}\text { Total natural habitat area in the } \\
\text { establishment }\end{array}$ & 4.00 & 100 & 2.0 & 100 & 4.00 & 100 & 15.00 & 100 \\
\hline $\begin{array}{l}\text { \% Natural habitats area in the } \\
\text { establishment }\end{array}$ & & $44 \%$ & & $20 \%$ & & $18 \%$ & & $18 \%$ \\
\hline
\end{tabular}

analytical instrumentation and farm managerial and administrative data. The system offers an expeditious, low cost, yet systematic procedure for sustainability assessment and environmental management of rural activities $^{1}$.

For the indicators of the Landscape ecology dimension, Geographic Information System techniques (aided by GPS, maps, and satellite images) were applied for composing sketches of the studied establishments, including accesses, limits, and infrastructure, as well as area calculation for all main agricultural land uses and natural habitats. Field-obtained geo-referential points were transferred onto available high resolution satellite images (Digital Globe, September $30^{\text {th }}, 2005$ ) allowing recognition, delimitation, and drawing of the several land occupation features onto the establishments' sketches.

Indicators related to water and soil quality were obtained in field and laboratory analyses. Some water quality indicators $\left(\mathrm{O}_{2}, \mathrm{pH}\right.$, conductivity, and turbidity) were measured in the field, with a Multi-parameter Horiba (U-10) probe. Nitrate was analyzed with a Merck RQFlex field colorimeter. Fecal coliform levels were estimated with Tecnobac (AlphaTecnoquímica) culture strips. Water samples were taken to the Embrapa Environment Laboratory for phosphate and chlorophyll determinations with a HACH spectrophotometer. Soil samples were sent to the Caratinga Municipal Agricultural Service Laboratory for routine macro-nutrients analyses.

Following the assessments carried out with the APOIA-NovoRural system, Environmental Management Reports were issued to all farmers, regarding the performance of their rural productive

\footnotetext{
${ }^{1}$ Details on the construction of the APOIA-NovoRural system and access to the operating set of scaling checklists refer to Rodrigues et al. (2010).
}

activities in both agronomic and environmental terms, including recommendations of practices and technology adoption for sustainable management. In the present study, opportunities for the implementation of forest recovery and agro-forestry areas were emphasized, aiming at promoting the connectivity of natural habitats, and especially the establishment of wildlife corridors between the CBS and other patches of natural forests in the vicinity, in order to favor eventual expansion of range for the local northern muriqui population. In a latest step of the research, a workshop was organized with the farmers and local administration agents to transfer the results of the field assessments and debate appropriate implementation measures (Pereira et al. 2007).

\section{RESULTS AND DISCUSSION}

All four studied establishments showed adequate general environmental performance levels, above the sustainability baseline defined in the APOIA-NovoRural system. Only two of the assessed sustainability dimensions presented mean values for the aggregated indicators below baseline levels in the majority of the assessments, namely the set of Soil quality indicators and the Management and administration indicators, except for establishment $\mathrm{D}$, in the latter dimension (Table 3).

In general, results for the indicators of the Landscape ecology dimension (indexes ranging from 0.68 to 0.83 ) attested to the good conservation status of natural habitats in the studied establishments, as well as adequate management performance for productive activities and measures for fire protection.

On the other hand, in two cases (establishments $\mathrm{B}$ and D), the indicator of Permanent Preservation 
Table 3. Results of the environmental assessments for the five sustainability dimensions considered in the APOIA-NovoRural system, obtained in the rural establishments selected as environmental management demonstration units around the Caratinga Biological Station (Minas Gerais State, Brazil).

\begin{tabular}{lcccc}
\hline \multicolumn{1}{c}{ Assessment Dimensions } & \multicolumn{2}{c}{ Establishment } \\
\cline { 2 - 5 } & $\mathrm{A}$ & $\mathrm{B}$ & $\mathrm{C}$ & $\mathrm{D}$ \\
\hline Landscape ecology & 0.78 & 0.74 & 0.83 & 0.68 \\
Environmental quality & & & 0.83 & 0.81 \\
$\quad$ Atmosphere & 0.84 & 0.78 & 0.82 & 0.93 \\
$\quad$ Water (and groundwater) & 0.90 & 0.83 & 0.62 & 0.42 \\
$\quad$ Soil & 0.60 & 0.59 & 0.73 & 0.77 \\
Socio-cultural values & 0.70 & 0.74 & 0.85 & 0.86 \\
Economic values & 0.78 & 0.82 & 0.48 & 0.74 \\
Management and administration & 0.58 & 0.48 & 0.75 & 0.72 \\
Sustainability indexes & 0.75 & 0.72 & & \\
\hline
\end{tabular}

Obs.: The whole set of performance indexes for all specific indicators are presented in Table 4.

Areas (PPA) was below the baseline compliance level (see Table 4, indicator 5). Enacted in the Brazilian Forest Code, under the $2^{\circ}$ paragraph of law 4.771, issued on September $15^{\text {th }}, 1965$, these PPAs are defined as "all forms of natural vegetation situated along water bodies, with minimum preserved width of 30 meters for streams narrower than $10 \mathrm{~m} ; 50 \mathrm{~m}$ for streams from $10 \mathrm{~m}$ to $50 \mathrm{~m}$ wide; $100 \mathrm{~m}$ for streams from $50 \mathrm{~m}$ to $200 \mathrm{~m}$ wide; $200 \mathrm{~m}$ for streams from $200 \mathrm{~m}$ to $600 \mathrm{~m}$ wide; and $500 \mathrm{~m}$ of preserved strip alongside streams wider than $600 \mathrm{~m}$. The PPAs include also the surroundings of water reservoirs (natural or artificial) and springs in a radius of $50 \mathrm{~m}$; the tops of hills and mountain ranges; the slopes with declivities superior to $45^{\circ}$; all dune and mangrove stabilizing vegetation; the borders of cliffs from the relief rupture; and areas above 1,800 $\mathrm{m}$ of altitude, regardless of vegetation type" (Brasil 1972). These PPAs are considered especially valuable areas for establishing wildlife corridors.

With regard to the other sustainability dimensions assessed in the APOIA-NovoRural system, almost all indicators related to impacts to the atmosphere (in the Environmental quality dimension) resulted above the compliance baseline (except for Noise, in establishment B). The adequate performance indexes obtained in this dimension were mostly due to the fact that no intentional burning has been practiced and machinery use has been minor in all establishments studied.

The mean results for the indicators of the Water quality dimension were well above the conformity baseline levels (ranging from 0.82 to 0.93 ), even though coliforms were ubiquitous due to widespread presence of cattle in or around all establishments.
In only one instance, oxygen levels were low, in a fish raising pond, in establishment $\mathrm{C}$, which led to a recommendation for the farmer to improve aeration and water flows. The favorable results observed for water quality indicators attested to the good conservation status of springs and streams in the studied area.

On the other hand, results for the indicators of the Soil quality dimension were well below the baseline levels (ranging from 0.42 to 0.62 ), confirming the very low natural soil fertility, combined with virtual absence of input use. The strong deficiency in phosphate and very high acidity levels measured in all establishments indicated the need for intervention, in order to promote agricultural productivity, be this related to crops or pastures.

Indicators of the Socio-cultural values dimension tended to comply with the sustainability baseline level of the APOIA-NovoRural system (ranging from 0.70 to 0.77 , Table 3 ), given the observed efforts to conserve and restore the existing historic farm houses and buildings, and associated with the modest but reasonably acceptable provision of public services, access to education, consumption standards, occupational safety and health (given the absence of pesticide handling in the studied establishments), and employment quality and opportunities. The indicators of the Economic values dimension also attested a favorable, though modest, general context (indexes ranging from 0.78 to 0.86 ), given the acceptable (relative to local standards) income generation and income sources diversity, good income distribution and indebtedness situation, and improvements in land value and dwelling quality observed in the studied establishments. 
Table 4. Full set of assessed indicators and environmental performance indexes obtained with the APOIA-NovoRural impact assessment system, in selected rural establishments neighboring the Caratinga Biological Station (Minas Gerais State, Brazil).

\begin{tabular}{|c|c|c|c|c|}
\hline \multirow[t]{2}{*}{ Dimensions and indicators } & \multicolumn{4}{|c|}{$\begin{array}{l}\text { Rural establishments and environmental } \\
\text { performance indexes }\end{array}$} \\
\hline & A & $\mathrm{B}$ & $\mathrm{C}$ & $\mathrm{D}$ \\
\hline 1. Natural habitats physiognomy and status & 0.83 & 0.84 & 0.96 & 0.99 \\
\hline 2. Management of agricultural production areas & 1.00 & 0.98 & 0.97 & 0.98 \\
\hline 3. Management of confined activities and animal husbandry & 0.62 & 0.82 & 0.95 & 0.74 \\
\hline 4. Conformity with mandatory Legal Preserve & 0.98 & 0.92 & 0.98 & 0.92 \\
\hline 5. Conformity with mandatory Permanent Preservation Areas & 0.78 & 0.23 & 0.88 & 0.13 \\
\hline 6. Ecological corridors & 0.71 & 0.69 & 0.76 & 0.68 \\
\hline 7. Landscape diversity & 0.66 & 0.58 & 0.47 & 0.31 \\
\hline 8. Productive diversity & 0.61 & 0.65 & 0.51 & 0.25 \\
\hline 9. Degraded areas reclamation & 0.88 & 0.76 & 0.77 & 0.63 \\
\hline 10. Incidence of vectors of endemic diseases & 0.68 & 0.66 & 1.00 & 0.69 \\
\hline 11. Endangered species/ local extinction risk & 0.75 & 0.80 & 0.90 & 0.90 \\
\hline 12. Fire risk & 1.00 & 1.00 & 1.00 & 0.76 \\
\hline 13. Geotechnical hazards & 0.70 & 0.70 & 0.70 & 0.82 \\
\hline \multicolumn{5}{|l|}{ Quality of environmental compartments dimension } \\
\hline \multicolumn{5}{|l|}{ Atmosphere } \\
\hline 14. Particulates/ smoke & 1.00 & 1.00 & 1.00 & 1.00 \\
\hline 15. Odor & 1.00 & 1.00 & 1.00 & 1.00 \\
\hline 16. Noise & 1.00 & 0.63 & 0.99 & 0.87 \\
\hline 17. Carbon oxide/ hydrocarbon emissions & 0.79 & 0.70 & 0.70 & 0.70 \\
\hline 18. Sulfur oxide emissions & 0.70 & 0.70 & 0.70 & 0.70 \\
\hline 19. Nitrogen oxide emissions & 0.70 & 0.70 & 0.70 & 0.70 \\
\hline \multicolumn{5}{|l|}{ Water } \\
\hline 20. Dissolved oxygen & 0.86 & 0.93 & 0.28 & 0.76 \\
\hline 21. Fecal coliforms & nd & 0.40 & nd & nd \\
\hline 22. $\mathrm{BOD}_{5}$ & nd & nd & nd & nd \\
\hline 23. $\mathrm{pH}^{5}$ & 0.84 & 0.99 & 0.83 & 0.83 \\
\hline 24. Nitrate & nd & nd & nd & nd \\
\hline 25. Phosphate & nd & nd & nd & nd \\
\hline 26. Turbidity & 0.72 & 1.00 & 0.83 & 1.00 \\
\hline 27. Chlorophyll & nd & nd & nd & nd \\
\hline 28. Conductivity & 0.95 & 0.95 & 0.95 & 0.95 \\
\hline 29. Visual water pollution & 1.00 & 1.00 & 1.00 & 1.00 \\
\hline 30. Pesticides potential impact & 1.00 & 1.00 & 1.00 & 1.00 \\
\hline \multicolumn{5}{|l|}{ Groundwater } \\
\hline 31. Fecal coliforms & nd & 0.20 & nd & nd \\
\hline 32. Nitrate & nd & nd & nd & nd \\
\hline 33. Conductivity & 0.95 & 0.95 & nd & 0.95 \\
\hline \multicolumn{5}{|l|}{ Soil quality } \\
\hline 34. Soil organic matter & 0.69 & 0.18 & 0,92 & 0.70 \\
\hline 35. $\mathrm{pH}$ & 0.59 & 0.78 & 0,99 & 0.59 \\
\hline 36. Phosphate & 0.07 & 0.14 & 0,08 & 0.06 \\
\hline 37. Exchangeable $\mathrm{K}$ & 0.97 & 0.90 & 0,95 & 0.60 \\
\hline 38. Exchangeable $\mathrm{Mg}$ (and $\mathrm{Ca}$ ) & 0.97 & 1.00 & 0,67 & 0.40 \\
\hline 39. Potential acidity $(\mathrm{H}+\mathrm{Al})$ & 0.29 & 0.23 & 0,29 & 0.06 \\
\hline 40. Sum of bases & 0.59 & 0.70 & 0,52 & 0.06 \\
\hline 41. Cation exchange capacity (CEC) & 0.96 & 0.97 & 0,96 & 0.97 \\
\hline 42. Base saturation & 0.27 & 0.29 & 0,25 & 0.08 \\
\hline 43. Erosion & 0.60 & 0.68 & 0,60 & 0.64 \\
\hline \multicolumn{5}{|l|}{ Sociocultural values dimension } \\
\hline 44. Access to education & 0.73 & 0.76 & 0.76 & 0.75 \\
\hline 45. Access to public services & 0.48 & 0.65 & 0.76 & 0.60 \\
\hline 46. Consumption standards & 0.63 & 0.79 & 0.63 & 0.67 \\
\hline 47. Access to sports and leisure & 0.70 & 0.70 & 0.50 & 0.74 \\
\hline 48. Conservation of historic, artistic, archaeological, and speleological legacy & 0.70 & 0.70 & 0.97 & 0.89 \\
\hline 49. Employment quality & 0.55 & 0.65 & 0.65 & 0.75 \\
\hline 50. Occupational safety and health & 0.83 & 0.75 & 0.79 & 0.81 \\
\hline 51. Local opportunity for higher qualification employment & 0.98 & 0.92 & 0.78 & 0.96 \\
\hline \multicolumn{5}{|l|}{ Economic values dimension } \\
\hline 52. Establishment net income & 1.00 & 1.00 & 1.00 & 1.00 \\
\hline 53. Diversity of income sources & 0.53 & 0.57 & 0.82 & 0.85 \\
\hline 54. Income distribution & 0.70 & 0.70 & 0.87 & 0.67 \\
\hline 55. Current indebtedness & 0.50 & 0.70 & 0.70 & 0.70 \\
\hline 56. Land value & 1.00 & 1.00 & 1.00 & 1.00 \\
\hline 57. Dwelling quality & 0.95 & 0.95 & 0.72 & 0.95 \\
\hline \multicolumn{5}{|l|}{ Management and administration dimension } \\
\hline 58. Manager profile and dedication & 0.67 & 0.67 & 0.67 & 0.67 \\
\hline 59. Commercialization conditions & 0.38 & 0.50 & 0.50 & 0.63 \\
\hline 60. Wastes management & nd & nd & nd & nd \\
\hline 61. Management of chemical inputs and residues & 0.60 & 0.40 & 0.60 & 1.0 \\
\hline 62. Institutional relationships & 0.67 & 0.33 & 0.17 & 0.67 \\
\hline
\end{tabular}


It was in the Management and administration dimension that most deficiencies were observed. Performance indexes in this dimension ranged from 0.48 to 0.74 , with establishment $\mathrm{D}$ being the only one to reach a score above 0.70 (Table 3 ). The indicators of this dimension showed that very constraining conditions for institutional relationship (lacking technical and legal assistance, cooperative association, and professional training) caused important deficiencies in the farmers' managerial capacity, such as use of accountancy and planning systems, and weak initiatives for waste recycling. Moreover, commercialization conditions were unfavorable, even if provisions for direct sales were in place (in small local markets), and means for minimum processing, storage and transportation, labeling and associated sales were poorly organized.

All of these results have been stressed in the individual Environmental Management Reports issued to the farmers, with recommendations of alternative agricultural practices and technology adoption for minimizing negative impacts and maximizing positive ones, aiming at improving their environmental, as well as their productive performances. Since only two of the assessed sustainability dimensions (Soil quality and Management and administration) tended to show mean values below baseline levels (Table 3), these recommendations were mostly concerned with soil fertility corrections in general, and indication of governmental provisions available to favor smallholders, among these, the most important regarded measures for formalization of the farmers' working situation, with respect to official social security programs, in order to secure personal rights to retirement and health care, official training programs, and technological affiliation opportunities to foster commercialization.

This integrative approach has been always the practice in the application of the APOIA-NovoRural system as a tool for environmental management and, in order to a farmer dedicate efforts to promote environmental conservation and recovery initiatives, a combination of complementary managerial, economic, and cultural capacities must be brought together and simultaneously addressed. In addition to the recommendations for improvement of environmental management practices, in all studied establishments, involving all sustainability dimensions included in the assessments, one immediate outcome has been reached for promoting natural habitat conservation and recovery. This involved improvements in the Landscape ecology indicators of establishment D the only one presenting a sustainability index below the compliance level for this dimension (Table 3).

Marked by adequate performance for most indicators, including Habitats status, Productive areas and Animal husbandry management, Threatened species protection, Fire and Geotechnical risks (Table 4), establishment D showed low Productive diversity (given dedication to dairy farming only) and relatively low Landscape diversity indexes, combined with a very low performance index for the Permanent Preservation Areas (PPA) indicator (Figure 2).

As presented in Figure 3, the scaling checklist corresponding to the "Compliance with Permanent Preservation Areas' indicator shows that $20 \%$ of the total area in establishment D is characterized as mandatory PPA and should be protected, according to the National Forest Code. However, the field survey carried out in the farm showed that, since the implementation of the main productive activity (market-oriented dairy farming, 2005), effective protection of that mandatory PPA has progressed from only $50 \%$ (in excellent conservation status) to $60 \%$, with recovery of an additional area corresponding to $10 \%$ of the PPA in the establishment, qualified in the field survey as being in good conservation status.

According to the APOIA-NovoRural model for this indicator (utility transformation function depicted in the graph of Figure 3), this situation resulted in a PPA index of -31.67 , which is translated

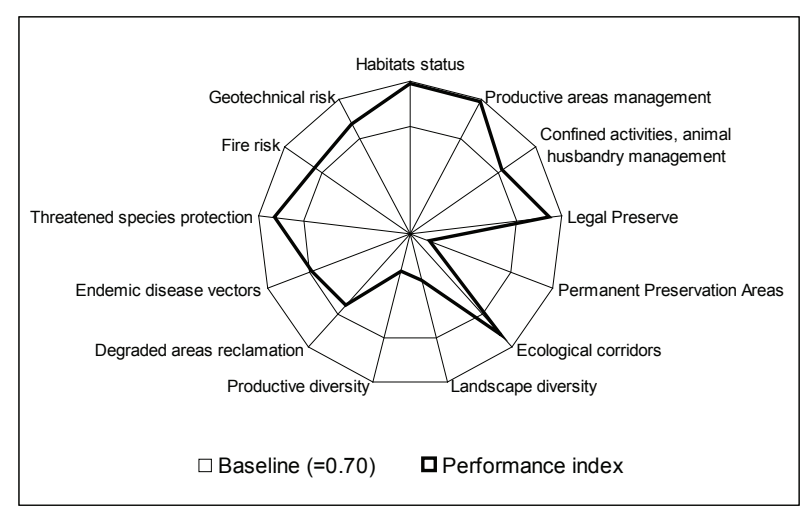

Figure 2. Results of the indicators in the Landscape ecology dimension for establishment $\mathrm{D}$, neighbor to the Caratinga Biological Station (Minas Gerais State, Brazil), according to the APOIA-NovoRural impact assessment system. 
as a 0.13 performance index, well below the compliance level of 0.70 defined as baseline for the indicators in the system.

Unsatisfied with this noncompliance and recognizing the relationship between correction of this indicator and the improvement of the environmental record of the establishment, the farmer agreed upon setting aside an additional area for recovery. Following recommendations drawn in the establishment sketch obtained in the field survey, this plot of land corresponded to a steep slope, where a shallow water table drains into a spring - an area of high priority for protection and compliant with the legal qualification as mandatory PPA.

Comprising just about 6 ha, this area represents $6.0 \%$ of the total area of establishment $\mathrm{D}$, sufficient to make its PPA compliant with legislation, and it is conveniently located in between the main lands of the CBS (957 ha, Fonseca 2003) and the second largest fragment ( $\sim 300 \mathrm{ha})$ of preserved forest in the watershed, allowing the conformation of a fauna corridor that represents a $30 \%$ increase in potential range for CBS' northern muriqui population. As can be seen in Figure $4 \mathrm{a}$, the main lands of the CBS to the north end abruptly in a pasture plot of establishment $\mathrm{D}$, along a slope that drains towards the stream crossing the farm from west to east. The

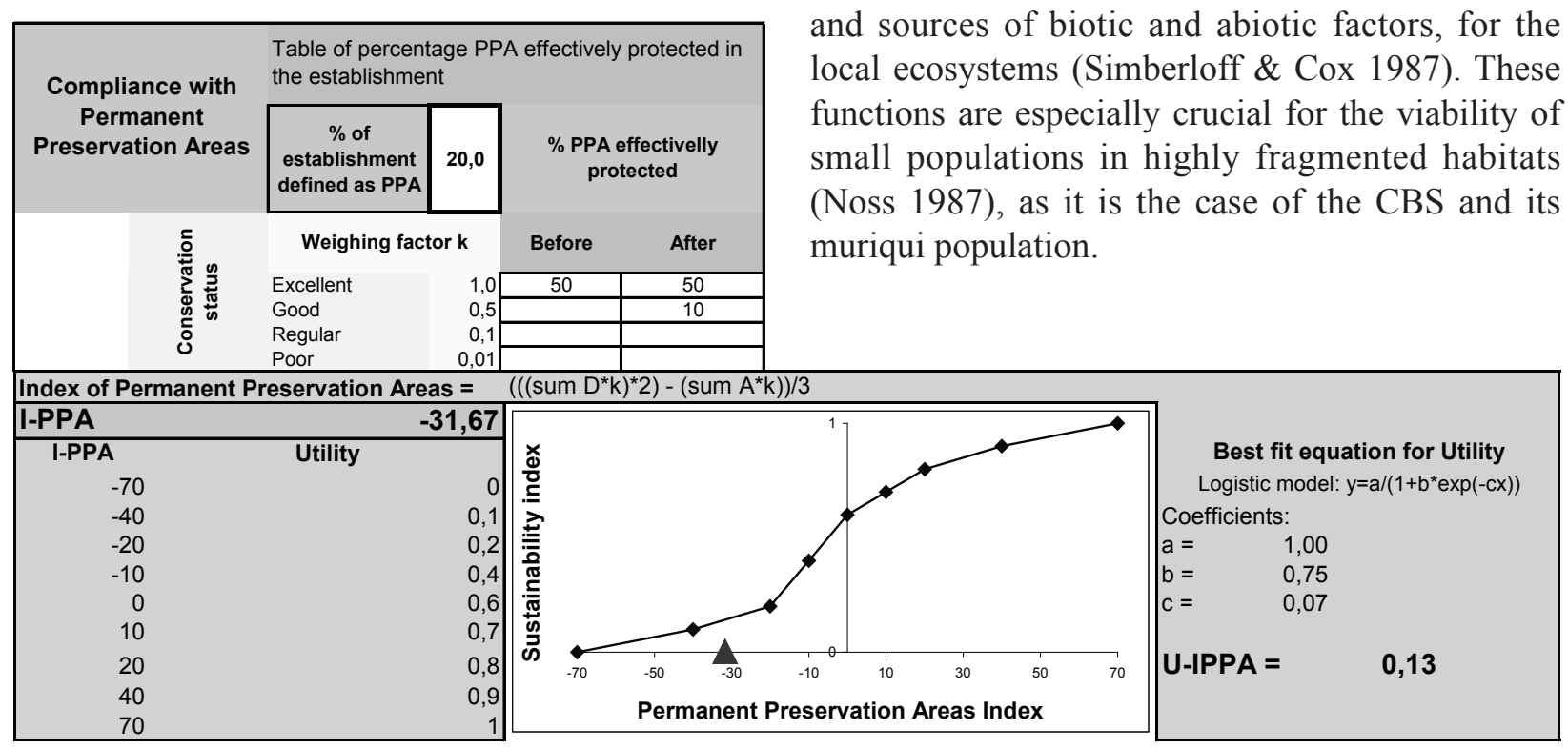

Figure 3. Result of the 'Compliance with Permanent Preservation Areas' indicator for establishment D, neighbor to the Caratinga Biological Station (Minas Gerais State, Brazil). This scaling checklist balances the area defined as PPA in the establishment and the area effectively protected to conform the Permanent Preservation Areas index (I-PPA = -31.67), which is then translated by a utility conversion function to the performance index for the indicator (U-IPPA $=0.13$ ). Similar scaling checklists are available for all 62 indicators in the APOIA-NovoRural system (Rodrigues et al. 2010). fauna corridor to correct the PPA indicator was then delineated to connect this area and the patch of recovering arboreal vegetation on the facing slope across the stream. A larger view of the area is presented in Figure 4b, showing the isolation of CBS, with respect to other forest fragments, the pastureland matrix of the surroundings, and the position of the fauna corridor delineated in establishment D.

This habitat recovery initiative presented in Figure 4 has been contracted and is already being established under the provisions of Promata (IEF 2007), an official government program that provides financial support, manpower and materials for fencing, preparing the soil and planting. The program offers samplings of native trees typical of the area for habitat reclamation, leaving the farmer with the responsibility of keeping the recovering vegetation, maintaining the fences, controlling cutting ants and other pests, and protecting the area from fire.

This initiative is a direct outcome of the present study, going beyond improvements in agricultural practices and technologies, to foster the recovery of forest patches and implementation of wildlife corridors. Important landscape functions are fulfilled by wildlife corridors, including proper habitat availability for existing species; media for movement, allowing connection among fragments and sub-populations; buffer areas for edge effects; and sources of biotic and abiotic factors, for the local ecosystems (Simberloff \& Cox 1987). These functions are especially crucial for the viability of small populations in highly fragmented habitats (Noss 1987), as it is the case of the CBS and its muriqui population. 


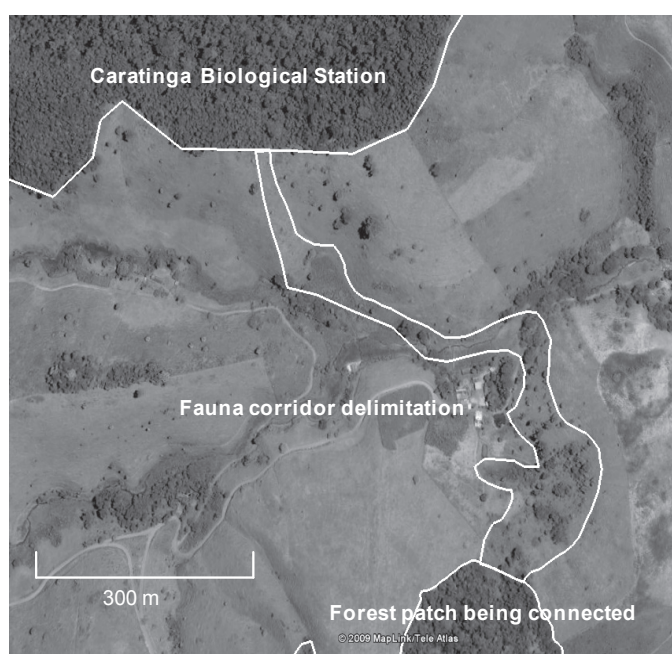

a) Delineation of the proposed fauna corridor for recovery of the mandatory Permanent Preservation Area indicator in Establishment D, according to the APOIA-NovoRural impact assessment.

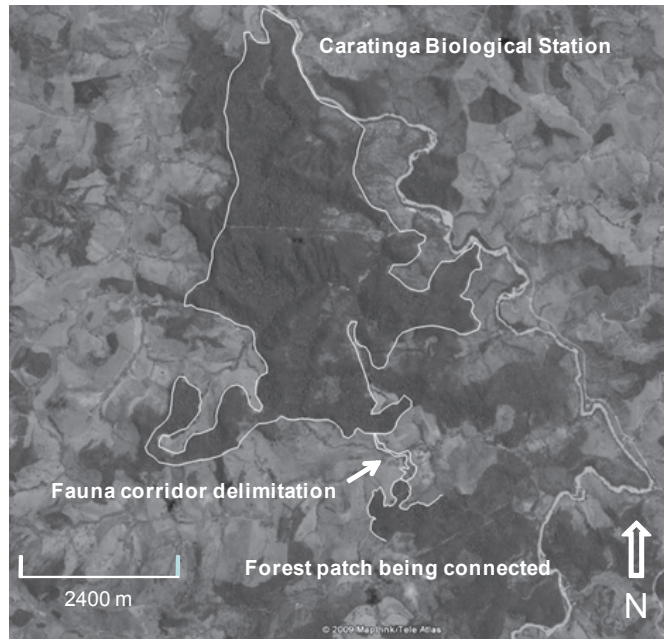

b) General view of the connectivity between the main lands of the Caratinga Biological Station and the second largest forest patch in the region, provided by the recovery of the Permanent Preservation Area in Establishment D.

Figure 4. Delimitation of a wildlife corridor (a) for compliance of the Permanent Preservation Area indicator in Establishment D and (b) connection between the main lands of the Caratinga Biological Station and the second largest forest patch existing in the region (Digital Globe image, September 30 $0^{\text {th }}, 2005$ ).

There are good prospects for such wildlife corridors to function as a means for expanding the range area of the northern muriqui population of the CBS. A previous work has shown that secondary recovering vegetation offers a more diversified diet, which is available during longer periods in the year and favors new range exploration and dispersion (Strier 1996). Extensive research on the demography and viability of this population indicated that favorable local conditions have been conducive to rapid population growth, increased home range sizes and frequent female migration (Strier 1991). Furthermore, and fundamental for devising management plans, it has been shown that dietary diversity, provided by abundant secondary and regenerating vegetation, has been crucial for supporting this population increase (Strier 2000).

The role of secondary vegetation is then particularly relevant for the management of CBS and its northern muriqui population: first and within the limits of the preserve, as a source of dietary support; and second, as a means of enlarging the range of the population, both by expanding the limits of the preserved area, and by extending wildlife corridors towards adjacent forest patches. Observations have confirmed that even exotic tree species and agro-forestry areas are quite effective in promoting movement and travel of primates among forest fragments (Luckett et al. 2004).

Even though comprising a small tract of forest recovery, representing about 6 ha of reforestation, the corridor being extended by recommendation of the current study may result in a considerable range expansion (300 ha) in the CBS. The combination of many such initiatives, engaging farmers all around the preserve, could multiply this effect. The involvement of the local government with incentives and support, such as provided by the Minas Gerais State Institute of Forestry (IEF 2007), is essential, in order to most efficiently organize the connectivity of natural habitats at the territorial scale, as well as to better promote rural development in favor of the farmers, in what has been called agri-environmental schemes (Donald \& Evans 2006).

The approach developed in the present study can be instrumental for strengthening these prospects, for it favors participatory engagement of farmers in improving their productive performance, as well as promoting environmental conservation and recovery in the rural areas around the CBS. The scaling up of such initiatives may help the extension of regionalscale wildlife corridors, such as the one being planned 
for implementation between the Minas Gerais and Espírito Santo States (Chiarello \& Melo 2001, Boubli et al. 2005), for connecting the largest remaining tracts of the Atlantic Rain Forest in the current natural range of the northern muriqui.

\section{CONCLUSION}

Integrated farm environmental management, as carried out with the APOIA-NovoRural impact assessment system, can provide a quantitative basis for decision making, regarding improvements in productive agricultural activities, as well as for rural landscape management. The approach can be instrumental for promoting biodiversity protection, both by favoring improvements in the quality of the rural environment and by allowing adequate selection of natural habitats for conservation. Simultaneously, the integrated environmental management approach developed in this study can contribute towards agricultural sustainability, favoring a synergy between biodiversity conservation and rural development.

\section{REFERENCES}

BANDEIRA, A. L. Análise dos efeitos da política de erradicação de cafeeiros: Caratinga a Manhuaçu, Minas Gerais - 1969. Viçosa: UFV, 1970.

BAYNE, E. M.; HOBSON, K. A. Comparing the effects of landscape fragmentation by forestry and agriculture on predation of artificial nests. Conservation Biology, Malden, v. 11, n. 6, p. 1418-1429, 1997.

BISSET, R. Methods for environmental impact assessment: a selective survey with case studies. In: BISWAS, A. K.; GEPING, Q. (Eds.). Environmental impact assessment for developing countries. London: Tycooly International, 1987. p. 3-64.

BOSSHARD, A. A methodology and terminology of sustainability assessment and its perspectives for rural planning. Agriculture, Ecosystems and Environment, Amsterdam, v. 77, n. 1-2, p. 29-41, 2000.

BOUBLI, J. P. et al. Ecology and conservation of northern muriquis at the Estação Biológica de Caratinga (EBC), MG, Brazil. In: ANNUAL MEETING OF THE SOCIETY FOR CONSERVATION BIOLOGY, 19., 2005, Brasília. Proceedings... Brasília, DF: UnB, 2005. p. 24.

BRASIL. Instituto Brasileiro de Desenvolvimento Florestal. Código florestal. Rio de Janeiro: IBDF, 1972.
BRITO, D.; GRELLE, C. E. V. Estimating minimum area of suitable habitat and viable population size for the northern muriqui (Brachyteles hypoxanthus). Biodiversity and Conservation, Heidelberg, v. 15, n. 5, p. 4197-4210, 2006.

BRITO, D.; GRELLE, C. E. V.; BOUBLI, J. P. Is the Atlantic Forest protected area network efficient in maintaining viable populations of Brachyteles hypoxanthus? Biodiversity and Conservation, Heidelberg, v. 17, n. 13 , p. 3255-3268, 2008.

BRUNER, A. G. et al. Effectiveness of parks in protecting tropical biodiversity. Science, Washington, v. 291, n. 5501, p. 125-128, 2001.

CHIARELLO, A. G.; MELO, F. R. de. Primate population densities and sizes in Atlantic Forest remnants of northern Espírito Santo, Brazil. International Journal of Primatology, New York, v. 22, n. 3, p. 379-396, 2001.

CLERGUE, B. et al. Biodiversity: function and assessment in agricultural areas: a review. Agronomy for Sustainable Development, Les Ulis, v. 25, n. 1, p. 1-15, 2005.

CONSERVATION INTERNATIONAL. Critically endangered primate protected from extinction. 2001. Available at: $<$ http://web.conservation.org/xp/news/press releases/2001/092401b.xml>. Access on: 10 Oct. 2007.

CROSSMAN, N. D. et al. Systematic landscape restoration in the rural-urban fringe: meeting conservation planning and policy goals. Biodiversity and Conservation, Heidelberg, v. 16, n. 13, p. 3781-3802, 2007.

CULLEN JÚNIOR, L. et al. Trampolins ecológicos e zonas de benefício múltiplo: ferramentas agroflorestais para a conservação das paisagens rurais fragmentadas na Floresta Atlântica Brasileira. Natureza \& Conservação, Curitiba, v. 1, n. 1, p. 37-46, 2003.

DAUGHERTY, H. E. Biodiversity conservation and rural sustainability: a case study of the Alexander Skutch Biological Corridor in Southern Costa Rica. Transactions on Ecology and the Environment, Southampton, v. 81, n. 1, p. 155-161, 2005.

DIAMOND, J. M. The island dilemma: lessons of modern biogeographic studies for the design of natural reserves. Biological Conservation, Amsterdam, v. 7, n. 2, p. 129146, 1975.

DONALD, P. F. Biodiversity impacts of some agricultural commodity production systems. Conservation Biology, Malden, v. 18, n. 1, p. 17-38, 2004.

DONALD, P. F.; GREEN, R. E.; HEATH, M. F. Agricultural intensification and the collapse of Europe's farmland bird populations. Proceedings of the Royal Society of London B, London, v. 268, n. 1462, p. 25-29, 2001. 
DONALD, P. F.; EVANS, A. D. Habitat connectivity and matrix restoration: the wider implications of agrienvironment schemes. Journal of Applied Ecology, Oxford, v. 43, n. 2, p. 209-218, 2006.

FAHRIG, L. Effects of habitat fragmentation on biodiversity. Annual Review of Ecology, Evolution and Systematics, Palo Alto, v. 34, s/n, p. 487-515, 2003.

FONSECA, M. T. da (Ed.). A RPPN Feliciano Miguel Abdala e os 20 anos da Estação Biológica de Caratinga. Belo Horizonte: Conservation International do Brasil, 2003.

HILTY, J. A. et al. Forecasting the effect of land-use change on native and non-native mammalian predator distributions. Biodiversity and Conservation, Heidelberg, v. 15 , n. 9 , p. 2853-2871, 2006.

HORSKINS, K.; MATHER, P. B.; WILSON, J. C. Corridors and connectivity: when use and function do not equate. Landscape Ecology, Dordrecht, v. 21, n. 5, p. 641-655, 2006.

INSTITUTO ESTADUAL DE FLORESTAS. Programa Promata: projeto de proteção da Mata Atlântica de Minas Gerais. 2007. Available at: $<$ http://www.redeambiente.org. br/promata.asp>. Access on: 30 Dec. 2008.

LAURANCE, W. F. et al. Ecosystem decay of Amazonian forest fragments: a 22-year investigation. Conservation Biology, Malden, v. 16, n. 3, p. 605-618, 2002.

LUCKETT, J. et al. Planted trees as corridors for primates at El Zota Biological Field Station, Costa Rica. Neotropical Primates, Arlington, v. 12, n. 3, p. 143-146, 2004.

MACARTHUR, R. H.; WILSON, E. O. The theory of island biogeography. Princeton: Princeton University Press, 1967.

MARTINI, A. M. Z. et al. A hot-point within a hot-spot: a high diversity site in Brazil's Atlantic Forest. Biodiversity and Conservation, Heidelberg, v. 16, n. 11, p. 3111-3128, 2007.

MARTINS, M. M. Density of primates in four semideciduous forest fragments of São Paulo, Brazil. Biodiversity and Conservation, Heidelberg, v. 14, n. 10, p. 2321-2329, 2005.

MAY, R. M. Island biogeography and the design of wildlife preserves. Nature, London, v. 254, s/n, p. 177-178, 1975.

MCNEELY, J. A.; SCHROTH, G. Agroforestry and biodiversity conservation: traditional practices, present dynamics, and lessons for the future. Biodiversity and Conservation, Heidelberg, v. 15, n. 2, p. 549-554, 2006.

MITTERMEIER, R. A. et al. Primates in peril: the world's 25 most endangered primates, 2004-2006. Primate Conservation, Arlington, v. 20, n. 1, p. 1-28, 2006.
MONTEIRO, R. C.; RODRIGUES, G. S. A system of integrated indicators for socio-environmental assessment and eco-certification in agriculture - Ambitec-Agro. Journal of Technology Management and Innovation, Santiago, v. 1, n. 3, p. 47-59, 2006.

MYERS, N. et al. Biodiversity hotspots for conservation priorities. Nature, London, v. 403, s/n, p. 853-858, 2000.

NORRIS, K. Agriculture and biodiversity conservation: opportunity knocks. Conservation Letters, Oxford, v. 1, n. 1, p. 2-11, 2008.

NOSS, R. F. Corridors in real landscapes: a reply to Simberloff and Cox. Conservation Biolology, Malden, v. 1, n. 2, p. 159-164, 1987.

OCHOA-GAONA, S. et al. Effect of forest fragmentation on the woody flora of the highlands of Chiapas, Mexico. Biodiversity and Conservation, Heidelberg, v. 13, n. 5, p. 867-884, 2004.

OPDAM, P.; WASCHER, D. Climate change meets habitat fragmentation: linking landscape and biogeographical scale levels in research and conservation. Biological Conservation, Oxford, v. 117, n. 3, p. 285-297, 2004.

PEREIRA, J. M. et al. Gestão ambiental de estabelecimentos rurais no entorno da RPPN Feliciano Miguel Abdala: implicações na conservação do muriqui do norte. In: BRAZILIAN CONGRESS OF PRIMATOLOGY, 12. 2007, Belo Horizonte. Proceedings... Belo Horizonte: Pontifícia Universidade Católica de Minas Gerais, 2007. 1 CD-ROM.

PONTUAL, F. B.; BOUBLI, J. P. The Caratinga Alliance: community-based conservation efforts to increase forest for the muriquis and water for the farmers. Neotropical Primates, Arlington, v. 13 (Suppl.), n. 1, p. 47-52, 2005.

PONTUAL, F. B. et al. A sustainable alliance to increase habitat for northern muriquis (Brachyteles hypoxanthus) and water for neighboring farmers in Caratinga, Brazil. In: ANNUAL MEETING OF THE SOCIETY FOR CONSERVATION BIOLOGY, 19., 2005, Brasília. Proceedings... Brasília, DF: Universidade de Brasília, 2005. p. 167.

PRESERVE MURIQUI. The Society for Muriqui's Preservation. 2007. Available at: $<\mathrm{http}: / / \mathrm{www}$. preservemuriqui.org.br/ing/home.htm>. Access on: 30 Dec. 2008.

RANTA, P. et al. The fragmented Atlantic rain forest of Brazil: size, shape and distribution of forest fragments. Biodiversity and Conservation, Heidelberg, v. 7, n. 3, p. 385-403, 1998.

RODRIGUES, G. S.; BUSCHINELLI, C. C. de A.; MUNIZ, L. R. Ostrich farming and environmental management tools: an overview. Australian Journal of Experimental Agriculture, Collingwood, v. 48, n. 10, p. 1308-1313, 2008a. 
RODRIGUES, G. S.; CAMPANHOLA, C. Sistema integrado de avaliação de impacto ambiental aplicado a atividades do Novo Rural. Pesquisa Agropecuária Brasileira, Brasília, DF, v. 38, n. 4, p. 445-451, 2003.

RODRIGUES, G. S. et al. Gestão ambiental de atividades rurais: estudo de caso em agroturismo e agricultura orgânica. Agricultura em São Paulo, São Paulo, v. 53, n. 1, p. 17-31, 2006.

RODRIGUES, G. S. et al. Gestão ambiental territorial na área de proteção ambiental da barra do Rio Mamanguape (PB). Boletim de Pesquisa e Desenvolvimento 50. Jaguariúna: Embrapa Meio Ambiente, 2008b.

RODRIGUES, G. S. et al. Integrated farm sustainability assessment for the environmental management of rural activities. Environmental Impact Assessment Review, Amsterdam, v. 30, n. 4, p. 229-239, 2010.

RODRIGUES, G. S. et al. Local productive arrangements for biodiesel production in Brazil: environmental assessment of smallholder's integrated oleaginous crops management. Journal of Agriculture and Rural Development in the Tropics and Subtropics, Kassel, v. 110, n. 1, p. 61-73, 2009.

RODRIGUES, G. S. et al. Socio-environmental impact of biodiesel production in Brazil. Journal of Technology Management and Innovation, Santiago, v. 2, n. 2, p. 4666, 2007.

RODRIGUES, G. S.; MOREIRA-VIÑAS, A. An environmental impact assessment system for responsible rural production in Uruguay. Journal of Technology Management and Innovation, Santiago, v. 2, n. 1, p. 4254, 2007.

SAUNDERS, D. A.; HOBBS, R. J.; MARGULES, C. R. Biological consequences of ecosystem fragmentation: a review. Conservation Biology, Malden, v. 5, n.1, p. 1832, 1991.
SILVA JÚNIOR, A. P. da; PONTES, A. R. M. The effect of a mega-fragmentation process on large mammal assemblages in the highly-threatened Pernambuco Endemism Centre, north-eastern Brazil. Biodiversity and Conservation, Heidelberg, v. 17, n. 6, p. 1455-1464, 2008.

SIMBERLOFF, D.; COX, J. Consequences and costs of conservation corridors. Conservation Biology, Malden, v. 1, n. 1, p. 63-71, 1987.

STRIER, K. B. Demography and conservation of an endangered primate, Brachyteles arachnoids. Conservation Biology, Malden, v. 5, n. 2, p. 214-218, 1991.

STRIER, K. B. Viability analysis of an isolated population of Muriqui monkeys (Brachyteles arachnoides): implications for primate conservation and demography. Primate Conservation, Arlington, v. 14-15, n. 1, p. 4352, 1996.

STRIER, K. B. Population viabilities and conservation implications for muriquis (Brachyteles arachnoids) in Brazil's Atlantic Forest. Biotropica, Malden, v. 32, n. 4b, p. 903-913, 2000.

STRIER, K. B. et al. Human dimensions of northern muriqui conservation efforts. Ecological and Environmental Anthropology, Athens (GA), v. 2, n. 2, p. 44-53, 2006.

STRIER, K. B. et al. Top 25 most endangered primates northern muriqui. IUCN / SSC Primate Specialist Group. 2004. Available at: $<$ http://www.primate-sg.org/muriquis. htm>. Access on: 06 Oct. 2007.

UEZU, A.; BEYER, D. D.; METZGER, J. P. Can agroforest woodlots work as stepping stones for birds in the Atlantic forest region? Biodiversity and Conservation, Heidelberg, v. 17, n. 8, p. 1907-1922, 2008.

VANCLAY, J. K. How to foster good husbandry of private native forests. Small-scale Forestry, Dordrecht, v. 6, n. 2, p. 205-218, 2007. 